\title{
Phycoremediation of contaminated water by cadmium (Cd) using two cyanobacterial strains (Trichormus variabilis and Nostoc muscorum)
}

\author{
Mona M. Abd El-Hameed', Mohamed E. Abuarab ${ }^{1 *}\left(\mathbb{C}\right.$, Nadhir Al-Ansari2 $^{2 *}$, Shady Abdel Mottaleb ${ }^{3}$, \\ Gomaa A. Bakeer ${ }^{1}$, Yeboah Gyasi-Agyei ${ }^{4}$ and Ali Mokhtar ${ }^{1}$
}

\begin{abstract}
Background: Water pollution with heavy metals is a severe dilemma that concerns the whole world related to its risk to natural ecosystems and human health. The main objective was to evaluate the removal efficiency of Cd of various concentrations from contaminated aqueous solution by use of two cyanobacterial strains (Nostoc muscorum and Trichormus variabilis). For this purpose, a specially designed laboratory pilot-scale experiment was conducted using these two cyanobacterial strains on four different initial concentrations of $\mathrm{Cd}\left(0,0.5,1.0\right.$ and $\left.2.0 \mathrm{mg} \mathrm{L}^{-1}\right)$ for 21 days.

Results: N. muscorum was more efficient than T. variabilis for removing $\mathrm{Cd}$ (II), with the optimum value of residual $\mathrm{Cd}$ of $0.033 \mathrm{mg} \mathrm{L}^{-1}$ achieved by $\mathrm{N}$. muscorum after 21 days with initial concentration of $0.5 \mathrm{mg} \mathrm{L}^{-1}$, translating to removal efficiency of $93.4 \%$, while the residual $\mathrm{Cd}$ (II) achieved by T. variabilis under the same conditions was $0.054 \mathrm{mg} \mathrm{L}^{-1}$ (89.13\% removal efficiency). Algal growth parameters and photosynthetic pigments were estimated for both cyanobacterial strains throughout the incubation period.
\end{abstract}

Conclusions: High Cd concentration had a more toxic impact on algal growth. The outcomes of this study will help to produce treated water that could be reused in agrarian activities.

Keywords: Phycoremediation, Cyanobacteria, Cd removal, Contaminated water, Wastewater

\section{Introduction}

One of the global challenges is the pollution of water bodies by heavy metals. Any metal and metalloid element having density within the range of 3.5 to $7 \mathrm{~g} \mathrm{~cm}^{-3}$ is considered poisonous even if present in low concentrations [20]. An optimum low level of concentration of heavy metals such as iron $(\mathrm{Fe})$, copper $(\mathrm{Cu})$ and zinc $(\mathrm{Zn})$ have biological usefulness while others, including lead $(\mathrm{Pb})$

\footnotetext{
*Correspondence: Mohamed.aboarab@agr.cu.edu.eg; nadhir.alansari@ltu.se

${ }^{1}$ Agricultural Engineering Department, Faculty of Agriculture, Cairo

University, Giza 12613, Egypt

${ }^{2}$ Environmental and Natural Resources Engineering, Lulea University

of Technology, 97187 Lulea, Sweden

Full list of author information is available at the end of the article
}

and cadmium $(\mathrm{Cd})$, are not useful biologically and are toxic irrespective of the level of contamination [24].

Cadmium (Cd) is one of the most noxious heavy metals that could reach the food chain through absorption by plants from the soil $[48,50]$. Human activities (e.g., mining, electronics, and metallurgical industries) are sources of $\mathrm{Cd}$ that causes contamination of water and soil [23, 33, 41]. Nordberg et al. [46] stated Cd absorbed from the soil by field crops, such as wheat, rice, and potatoes, has negative effects on human bones. In Japan, water and soil contaminated by $\mathrm{Cd}$ is the major cause of the Itai-itai disease [35]. Cadmium causes bone disease, kidney damage and cancer. It is reported 
that high levels of $\mathrm{Cd}$ exposure cause osteoporosis, renal dysfunction, and liver damage [21].

The manufacture of alkaline batteries consumes about three-quarters of $\mathrm{Cd}$ production. The remaining one-quarter is used by processes including coating materials and as a plastic stabilizer [32]. Cadmium is extremely poisonous, causes plant nutrient deficiency and oxidative stress, and also impacts on the enzymatic systems of cells [31, 32]. Therefore, World Health Organization (WHO) recommends that the concentration of $\mathrm{Cd}$ in potable water should be limited to $3 \mu \mathrm{g}$ $\mathrm{L}^{-1}$ [65]. For short- and long-term irrigation water use, the preferred threshold of $\mathrm{Cd}$ concentration should be 0.05 and $0.01 \mathrm{mg} \mathrm{L}^{-1}$, respectively $[17,56]$.

Human health issues related to the pollution of water bodies and soil by heavy metals resulting from pesticides, fertilizers, sewage water and industrial activities have received global attention. There is a lack of precautionary measures put in place to inspect industrial facilities that discharge contaminated wastewater into agricultural drains that supply irrigation water for production of crops in many countries, be it developing or developed. Thus, people who handle the contaminated irrigation water and the resulting agricultural products put their health at risk $[8,14,60]$. Many different methods of wastewater treatment (physical, chemical treatment, biological and phytoremediation) have been applied to reduce $\mathrm{Cd}$ concentration in water to the recommended international standards [11]. Some of the wastewater treatments applied include physicochemical processes (ion exchange and chemical precipitation), electrochemical treatments (electrocoagulation, electrodeposition, and electro-flotation), adsorption (carbon nanotubes, activated carbon and wood sawdust adsorbents), and the most common current methods are photocatalysis, membrane filtration, and nanotechnology $[9,12,61,63,64]$.

However, these techniques have many disadvantages. For example, they are costly, consume high energy, have potential of secondary pollution and are only valid within a range of $\mathrm{Cd}$ concentration [35, 41]. Moreover, most of the conventional techniques do not provide $100 \%$ heavy metal removal with restrictions on $\mathrm{pH}$ variation are efficient at only smaller concentrations $[5,36]$, produce toxic sludge and waste products, and need high exploitation and recycling costs [39, 47]. Being environmentally friendly, biotechnology techniques have received significant attention. In addition, they provide high heavy metal removal efficiency, consume less energy, and are carried out at lower pressure and temperature $[18,57]$. However, availability of selected biomass types for the biosorbent is of primary importance. Biosorbents can be nature based (e.g., bacteria, fungi and algae) or from industrial and agricultural wastes. Several studies have used biosorbents for dye and metal treatments $[38,62]$.

Phycoremediation is any process that use algae to bioremediate contaminated water and wastewater [49]. The characteristics of algae involve a high ratio of surface area to volume, high heavy metals tolerance, growth possibility either autotrophically or heterotrophically, the ability for genetic manipulation, phytochelatin expression and phototaxy [37]. Biosorption using blue-green algae (cyanobacteria) is rich in vitamins and proteins. The biomass can absorb and adsorb heavy metals from aquatic solution even when the cells are dead. Unlike conventional methods, cyanobacteria processes do not produce polluting sludges, are highly effective, easy to operate and cost effective for treating large quantities of wastewater with low contaminant concentrations $[19,51]$. Cyanobacteria are exemplary biosorbents and are commonly found in ecosystems of water and soil $[10,13]$.

There were three objectives of this study: i) evaluation of the removal efficiency of $\mathrm{Cd}$ from an aqueous solution by the use of two cyanobacterial strains (Nostoc muscorum and Trichormus variabilis (Anabaena variabilis)) in a specially designed laboratory pilot-scale experiment; ii) investigation of the influence of various concentrations of $\mathrm{Cd}$ on algae growth parameters, and iii) treatment of wastewater to the WHO standard for reuse for agrarian activities.

\section{Materials and methods}

\section{Algae and culturing conditions}

Two cyanobacterial strains (Nostoc muscorum and Trichormus variabilis) were cultured in a BG110 liquid medium consisting of a mixture of $\mathrm{MgSO}_{4}, \mathrm{~K}_{2} \mathrm{HPO}_{4}$, $\mathrm{CaCl}_{2}, \mathrm{Na}_{2} \mathrm{EDTA}, \mathrm{Na}_{2} \mathrm{CO}_{3}$, citric acid, and ferric ammonium citrate as presented by Ripkka et al. [54]. Erlenmeyer flasks were used with daily alternation of an average of $8 \mathrm{~h}$ of darkness and $16 \mathrm{~h}$ of light. The temperature was controlled during the experiment at $27 \pm 2{ }^{\circ} \mathrm{C}$, while the cool white light intensity ranged from 3000 to $3500 \mathrm{~lx}$ and the $\mathrm{pH}$ was set to 7.2. The algae cells were harvested on the 15th day, which corresponds to the middle of the logarithmic phase, and centrifuged at $3000 \mathrm{rpm}$ for $10 \mathrm{~min}$.

\section{Preparation of metal/toxin stock solutions}

The cadmium-contaminated aqueous solution was prepared by adding $0.684 \mathrm{~g}$ of cadmium sulfate $\left(\mathrm{CdSO}_{4} \cdot 8 \mathrm{H}_{2} \mathrm{O}\right)$ to $100 \mathrm{~cm}^{3}$ of distilled water and stirring well to ensure that the cadmium sulfate was completely dissolved. The prepared solution was diluted using the medium to obtain the desired concentrations of $0,0.5,1$ and $2 \mathrm{mg} \mathrm{L}^{-1}$ used in the experiments. Three replicates for each concentration treatment were set up. 


\section{Experimental setup}

The experiments were carried out using plastic containers having dimensions of $26.9 \mathrm{~cm}$ in length, $18.75 \mathrm{~cm}$ in width and $12.5 \mathrm{~cm}$ in depth. Each container was filled with a mixture of $2 \mathrm{~L}$ of the prepared aqueous solution (BG110 medium) of different $\mathrm{Cd}$ concentrations and $110 \mathrm{ml}$ of the algae medium $\left(\mathrm{OD}_{678}\right)$. Samples were taken from the plastic containers at a rate of $5 \mathrm{ml}$ every 4 days to measure the optical density (OD), while samples were taken in volumes of $50 \mathrm{ml}$ every 7 days $\left(\mathrm{D}_{0}, \mathrm{D}_{7}, \mathrm{D}_{14}, \mathrm{D}_{21}\right)$ for the determination of the photosynthetic pigments, and a sample of $50 \mathrm{ml}$ was taken at the end of the incubation period of 21 days to measure biomass content.

\section{Heavy metal removal efficiency}

Five $\mathrm{ml}$ samples were taken from the contaminated media every four days to estimate the concentration of residual $\mathrm{Cd}$ caused by algae absorption using an atomic absorption spectrometer (Perkin Elmer Analyst 400). The removal efficiency (RE) was calculated as:

$$
\text { Heavy metal removal efficiency }=\left(\frac{C_{o}-C_{1}}{C_{o}}\right) \times 100,
$$

where $\mathrm{C}_{1}$ and $\mathrm{C}_{\mathrm{o}}$ are, respectively, the residual and initial concentrations of $\mathrm{Cd}$ in $\mathrm{mg} \mathrm{L}^{-1}$.

\section{Photosynthetic pigments analysis}

The samples were subjected to 10-min centrifugation at $4000 \mathrm{rpm}$, after which the algae medium was carefully added before the distilled water was carefully poured with the algal cell suspension into a $4 \mathrm{ml}$ DMSO solution. The mixture was stirred at $1000 \mathrm{rpm}$ for $1 \mathrm{~min}$ to reach homogeneity, after which it was heated for $10 \mathrm{~min}$ in a water bath at $65{ }^{\circ} \mathrm{C}$. Six $\mathrm{ml}$ of $95 \%$ acetone concentration was added to the algal cells extracted from the DMSO solution and mixed thoroughly. The photosynthesis pigments concentrations of Chlorophyll A and carotenoids were estimated in $\mu \mathrm{g} \mathrm{ml}^{-1}$ according to the Ritchie [55] and Davies [15] methods, respectively.

\section{Statistical analysis}

The statistical analysis involved the use of a random complete block design (RCBD) with factorial data analysis, the three factors considered being concentration (C), algae (A), and number of days (D). Three replications were implemented in order to minimize parameter errors. The least significant differences (LSD) and correlation coefficient (CC) test were applied [59]. MSTAT software [45] was used for the statistical analysis.

\section{Results and discussion}

\section{Removal of heavy metal}

There was a significant variation of residual $\mathrm{Cd}$ values among the different initial $\mathrm{Cd}$ concentrations considered. As shown in Fig. 1, the residual Cd tends to stabilize after day 12 for all initial concentrations. N. muscorum achieved a terminal residual $\mathrm{Cd}$ value of $0.033,0.175$ and $0.51 \mathrm{mg} \mathrm{L}^{-1}$ for the initial concentration of $0.5,1$ and $2 \mathrm{mg} \mathrm{L}^{-1}$, respectively, translating to heavy metal removal efficiency of 93.4, 82.5 and $74.5 \%$, respectively. Terminal residual $\mathrm{Cd}$ values achieved by $T$. variabilis were slightly higher at $0.054,0.26$ and $0.632 \mathrm{mg} \mathrm{L}^{-1}$ for the initial concentration of $0.5,1$ and $2 \mathrm{mg} \mathrm{L}^{-1}$, respectively, reflecting removal efficiency values of $89.13,74.00$ and $68.38 \%$, respectively (Fig. 1). Cadmium was released again into
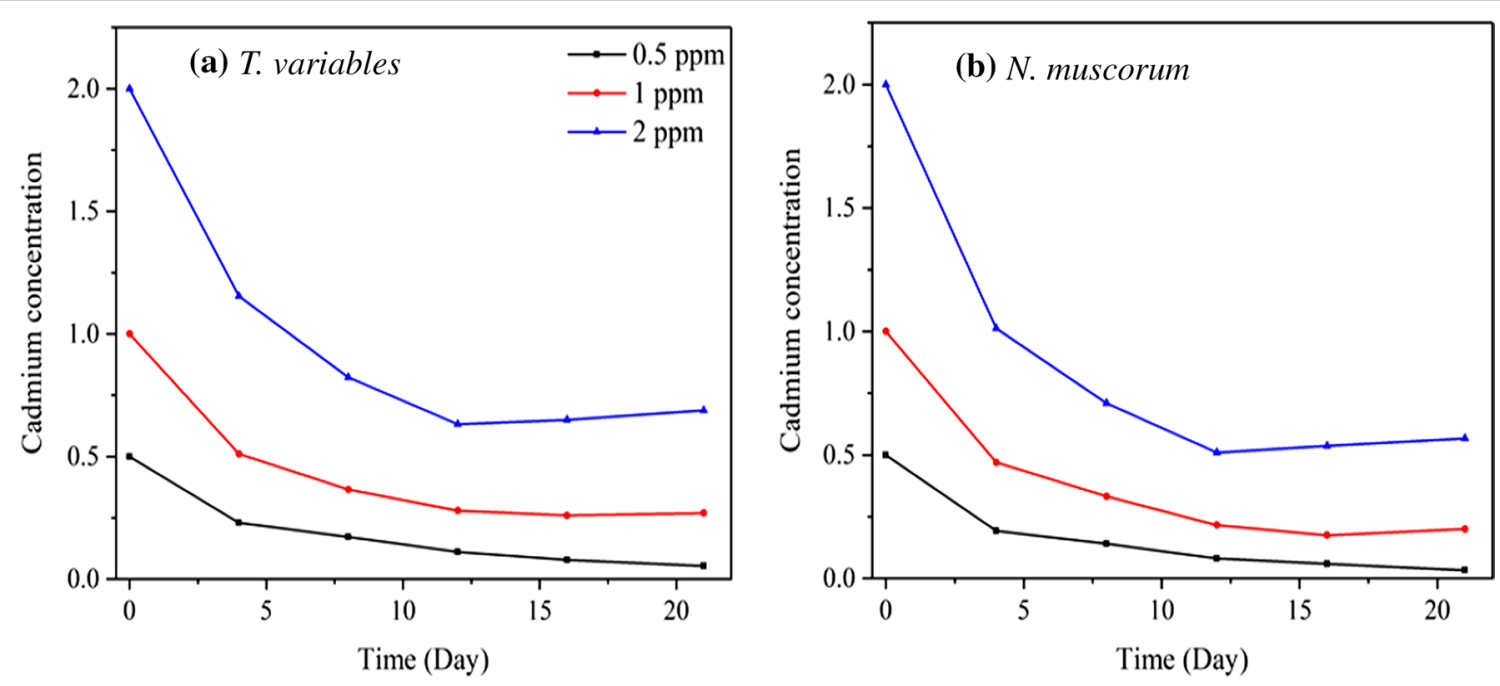

Fig. 1 Residual concentration of Cd treated by T. variabilis (a) and N. muscorum (b) for three different initial concentrations 
the contaminated water as a result of the algae's sorption decline related to the toxic effect of $\mathrm{Cd}$, and so the residual $\mathrm{Cd}$ marginally increased after 16 and 12 days for the initial concentrations of 1 and $2 \mathrm{mg} \mathrm{L}^{-1}$, respectively.

Our results of heavy metal removal were in agreement with Khan et al. [34] who showed that the removal efficiency of $\mathrm{Cd}$ by use of four freshwater algae (Zygnema insigne, Cladophora glomerata, Vaucheria debaryana, and Oedogonium westii) increased with time elapsed and reached the highest level on the $9^{\text {th }}$ day after which there was marginal change. The cyanobacterium Nostoc sp. JRD1 was used to remediate polluted water with different heavy metal ions from the reservoir of Hindustan Paper Corporation Limited, India, and showed a very high removal (94\%) capacity for $\mathrm{Cd}(\mathrm{II})$ upon exposure to $0.5 \mathrm{ppm}$ for $24 \mathrm{~h}$ [3].

Ahad et al. [2] achieved a removal efficiency of $92 \%$ of Cd by $N$. muscorum within 24 h from the initial concentration of $0.5 \mathrm{ppm}$. Hazarika et al. [25] reported Cd removal efficiency by $N$. muscorum of $82 \%$ after $30 \mathrm{~h}$ using 5 ppm initial concentration. Dixit and Singh [16] achieved a ceiling sorption of $\mathrm{Cd}$ of $85.2 \%$ at $60 \mu \mathrm{g} \mathrm{ml}$ concentration within $30 \mathrm{~min}$.

Anabaena sphaerica yielded removal efficiencies of $\mathrm{Cd}$ between 29 and 85\% [26]. Abdel-Aty et al. [1] indicated that the biosorption of $\mathrm{Cd}$ with Anabaena sphaerica was rapid in the first 20 min of the experiment followed by a gradual increase until attaining equilibrium at $90 \mathrm{~min}$ after which the biosorption was steady. Their results showed that the initial biosorption at $50 \mathrm{ppm}$ of $\mathrm{Cd}$ was 94.3\%, but decreased with increasing Cd concentration. Goswami et al. [22] reported that Anabaena doliolum recorded high $\mathrm{Cd}$ removal efficiency of $91.2 \%$ at the beginning and $68.6 \%$ at the $7^{\text {th }}$ day of exposure under different concentrations ranging from 0.5 to $2.0 \mathrm{mg} \mathrm{L}^{-1}$. Siva et al. [58] observed rapid biosorption at the beginning of the experiment with $\mathrm{Cd}$ concentration of $1 \mathrm{mg}$ $\mathrm{L}^{-1}$ achieving a removal efficiency of $74 \%$ within $6 \mathrm{~min}$, then reached equilibrium within 1 day with $93.9 \%$ of metal ions adsorbed by Spirulina (Arthrospira) indica. Inthorn et al. [30] presented the following removal efficiencies of $\mathrm{Cd}$ by the use of different species, namely T5 (94\%), Chlorococcum sp. (94\%), Scenedesmus acutus (88\%) Fischerella sp. (91\%) Chlorella vulgaris var. vulgaris (89\%), Nostoc sp. (94\%), Lyngbya hieronymusii (97\%), Oscillatoria jasorvensis (94\%), Gloeocapsa sp. (96\%), and Phormidium molle (95\%).

Additionally, Inthorn et al. [29] reported that more than $90 \%$ of Cd removal efficiency was achieved within $10 \mathrm{~min}$ at $1 \mathrm{ppm}$ initial concentration by Tolypothrix tenuis, after which the $\mathrm{Cd}$ concentration remained steady. Inthorn et al. [28] reported Cd removal efficiency of $84 \%$ and $92 \%$, respectively, in non-treated and $\mathrm{NaOH}$-treated cells of Nostoc paludosum, and for similar circumstances in Phormidium angustissimum reported 86\% and 94\%, respectively. The results confirmed that $30 \mathrm{~min}$ contact time was required for significant $\mathrm{Cd}$ removal and to reach the equilibrium state. Further experiments indicated $10 \mathrm{~min}$ is enough for significant removal capacity and to attain the equilibrium state.

\section{Alga growth parameters Alga biomass}

The highest biomass value for $N$. muscorum was $533.3 \mathrm{mg}$ $\mathrm{L}^{-1}$ at the end of the 21 days of the experiment for the control treatment ( 0.0 concentration), while the lowest value of $\mathrm{Cd}$ was $200 \mathrm{mg} \mathrm{L}^{-1}$ after 21 days for the initial concentration of $2 \mathrm{ppm}$ (Fig. 2). The decline phase was approximately reached under $\mathrm{Cd}$ concentrations of 1 and $2 \mathrm{mg} \mathrm{L}^{-1}$ after 16 days of incubation period. A biomass of $300 \mathrm{mg} \mathrm{L}^{-1}$ was recorded for T. variabilis in the control treatment while the lowest biomass was $50 \mathrm{mg} \mathrm{L}^{-1}$ for the initial $2 \mathrm{mg} \mathrm{L}^{-1} \mathrm{Cd}$ concentration at the end of the experiment.

The highest initial concentration of $\mathrm{Cd}$ reduced growth of biomass and led to cyanobacteria death [25]. Only 5 to 6 days of incubation period was required for cadmium to delay the algae growth. $\mathrm{Cd}$ replaced the $\mathrm{Mg}$ in the chlorophyll molecule of the algae and affected photosynthesis, leading to a reduced growth of the cells, particularly the more sensitive N. muscorum cells [40]. Siva et al. [58] stated that $\mathrm{Cd}$ concentration of $10 \mathrm{mg} \mathrm{L}^{-1}$ is extremely poisonous and inhibited Spirulina (Arthrospira) indica growth, the growth inhibition increasing with the concentration of $\mathrm{Cd}$ in the aqueous solution. Arunakumara and Zhang [6] demonstrated that $\mathrm{Cd}$ concentrations of 1, 2, 4, 6 and $8 \mathrm{mg} \mathrm{L}^{-1}$ inhibited the growth of Synechocystis sp. PCC 6803 at 2 days into the incubation period of 8 days. Similarly, the cyanobacterium (Anabaena flosaquae) needed just $0.15 \mathrm{mg} \mathrm{L}^{-1}$ concentration of $\mathrm{Cd}$ to inhibit its growth by $50 \%$ [27]. Meanwhile, Rehman and Shakoori [52] observed Chlorella in the control experiment grew gradually but, when treated with a culture of $8 \mu \mathrm{g} \mathrm{ml}^{-1}$ of Cd, the growth of cells decreased.

\section{Optical density (OD)}

The growth rate of algae cells was affected slightly at $0.5 \mathrm{ppm}$ concentration of $\mathrm{Cd}$, whereas concentration levels of 1 and $2 \mathrm{ppm}$ completely inhibited growth by the middle of the experiment for both cyanobacterial strains (Fig. 3). Rangsayatorn et al. [53] specified that optical density of Spirulina platensis was affected by higher concentrations of $\mathrm{Cd}$ that caused the death of cyanobacterial cells, while insignificant growth suppression was observed at lower concentrations. 


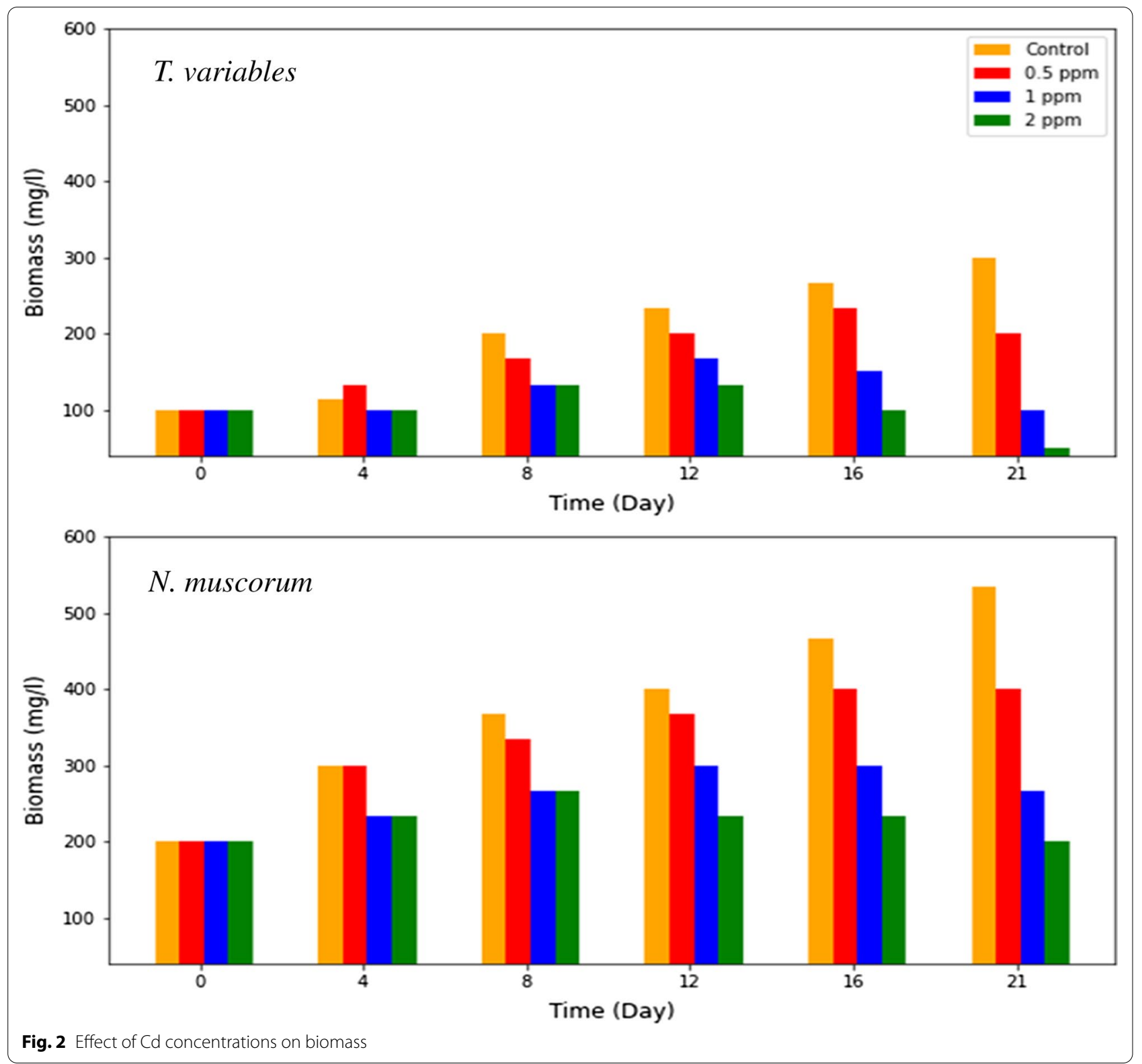

\section{Pigments}

The reduction in Chlorophyll A was minimal at $0.5 \mathrm{ppm}$ initial $\mathrm{Cd}$ concentration during the incubation period (Fig. 4), but significant reductions were detected at concentrations of 1 and $2 \mathrm{mg} \mathrm{L}^{-1}$ in the cases of the two cyanobacterial strains. Likewise, carotenoids displayed a similar trend, even though $N$. muscorum showed nearly a constant value for the $0.5 \mathrm{ppm}$ initial concentration (Fig. 5).

The results obtained for the pigments agreed with Atri and Rai [7] who stated that higher dosages of Cd reduced Chlorophyll A and carotenoids of Anabaena, Microcystis, and Nostoc. Similarly, Goswami et al. [22] showed that higher concentrations of $\mathrm{Cd}$ decreased the pigments of Anabaena doliolum. Alidoust et al. [4] reported that Nostoc entophytum ISC32' cells exposure to $2 \mathrm{mg} \mathrm{L}^{-1} \mathrm{Cd}$ resulted in $65.77 \%$ reduction in Chlorophyll A.

Mota et al. [44] reported a decline in Chlorophyll A content for the cultures treated with $\mathrm{Cd}$ for Cyanothece species CCY 0110 at $24 \mathrm{~h}$ exposure, and the decline gradually continued thereafter. Lamaia et al. [42] observed that high concentrations of $\mathrm{Cd}$ could eliminate chloroplasts in Cladophora fracta [42]. In a similar study, Arunakumara and Zhang [6] showed that pigments content (Chlorophyll A and carotenoids) 


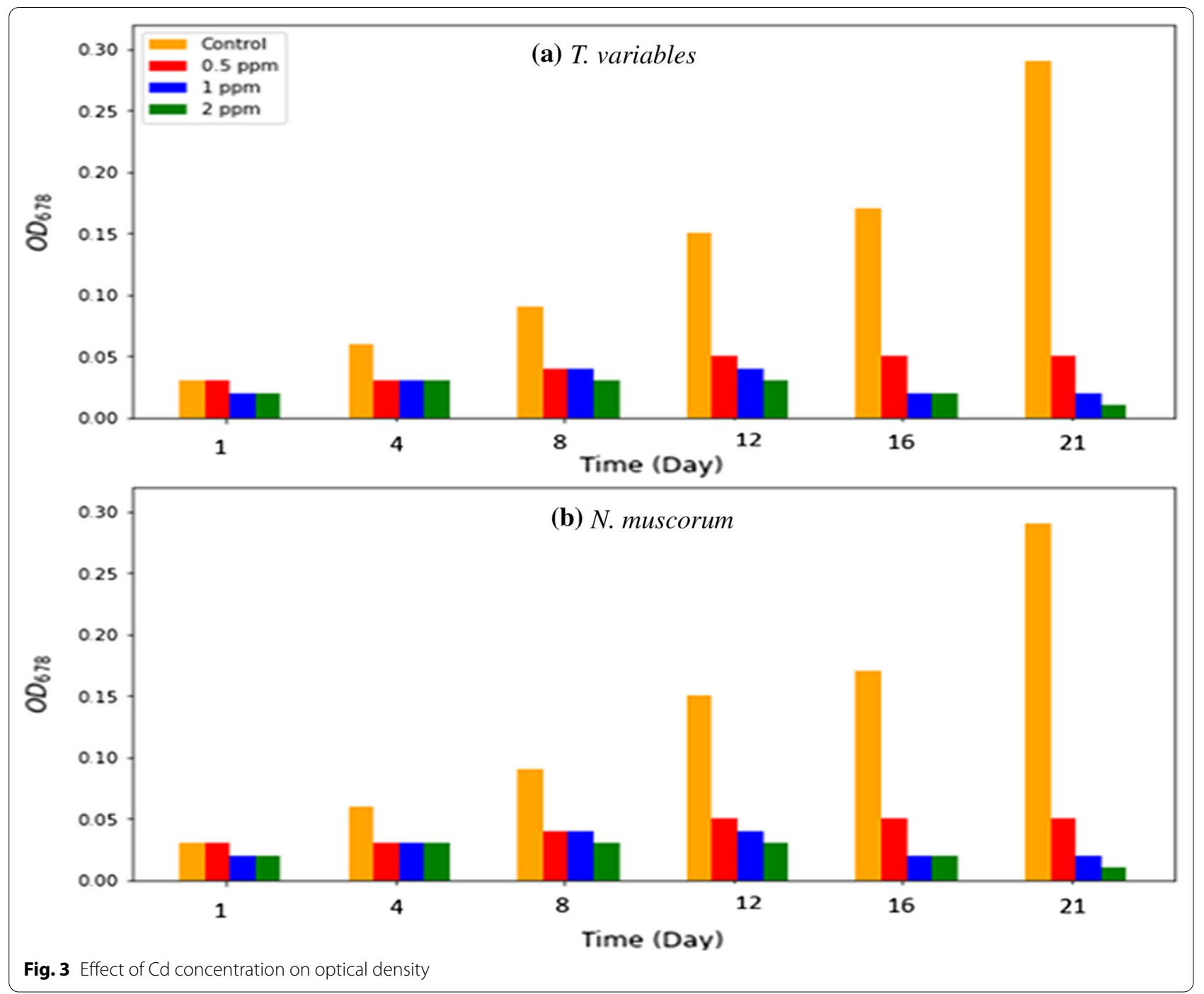

decreased with increasing $\mathrm{Cd}$ concentration, and the damage to the photosynthetic pigments is related to $\mathrm{Cd}$ toxicity [43].

\section{Statistical analysis}

The results of T. variabilis and $N$. muscorum were significantly different at the 0.05 level of significance for the individual treatments (Table 1). However, the $3 \mathrm{fac}-$ tors (concentrations, days and algae) did not show any significant difference with respect to biomass at the 0.05 significance level. It is observed that $N$. muscorum has a higher removal efficiency of $\mathrm{Cd}$ from pigments and contaminated water and is thus preferred. Nevertheless $T$. variabilis showed superior quality in $\mathrm{OD}$ values.

There were significant differences between values under different initial $\mathrm{Cd}$ concentrations at the 0.05 significance level. It is observed that the best results were achieved in terms of residual $\mathrm{Cd}, \mathrm{OD}$, Chlorophyll A, and carotenoids by the control treatment $\left(\mathrm{C}_{0}\right)$, followed by the $2^{\text {nd }}$ concentration $\left(\mathrm{C}_{0.5}\right)$, while the 4 th concentration $\left(\mathrm{C}_{2}\right)$ accomplished the lowest results. However, there was non-significant difference between $C_{1}$ and $C_{2}$ in relation to OD values. Days $12\left(D_{12}\right), 16\left(D_{16}\right)$ and $21\left(D_{21}\right)$ did not exhibit any significant statistical differences. However, $\left(D_{21}\right)$ achieved the best result with respect to OD. Pigments as well exhibited significant differences at the 0.05 level (Table 2).

It turned out that $T$. variabilis was the best alga in pigment towards the end of the study period with the case of no Cd treatment $\left(\mathrm{A}_{2} \mathrm{C}_{0} \mathrm{D}_{21}\right)$. The coefficient of determination $\left(\mathrm{R}^{2}\right)$ values between residual $\mathrm{Cd}$ and biomass for N. muscorum and T. variabilis were $37.02 \%$ and $10.88 \%$, respectively. Meanwhile, $R^{2}$ values between residual $\mathrm{Cd}$ and $\mathrm{OD}_{678}$ were $17.54 \%$ and $6.66 \%$, respectively, for $N$. muscorum and T. variabilis, while the 

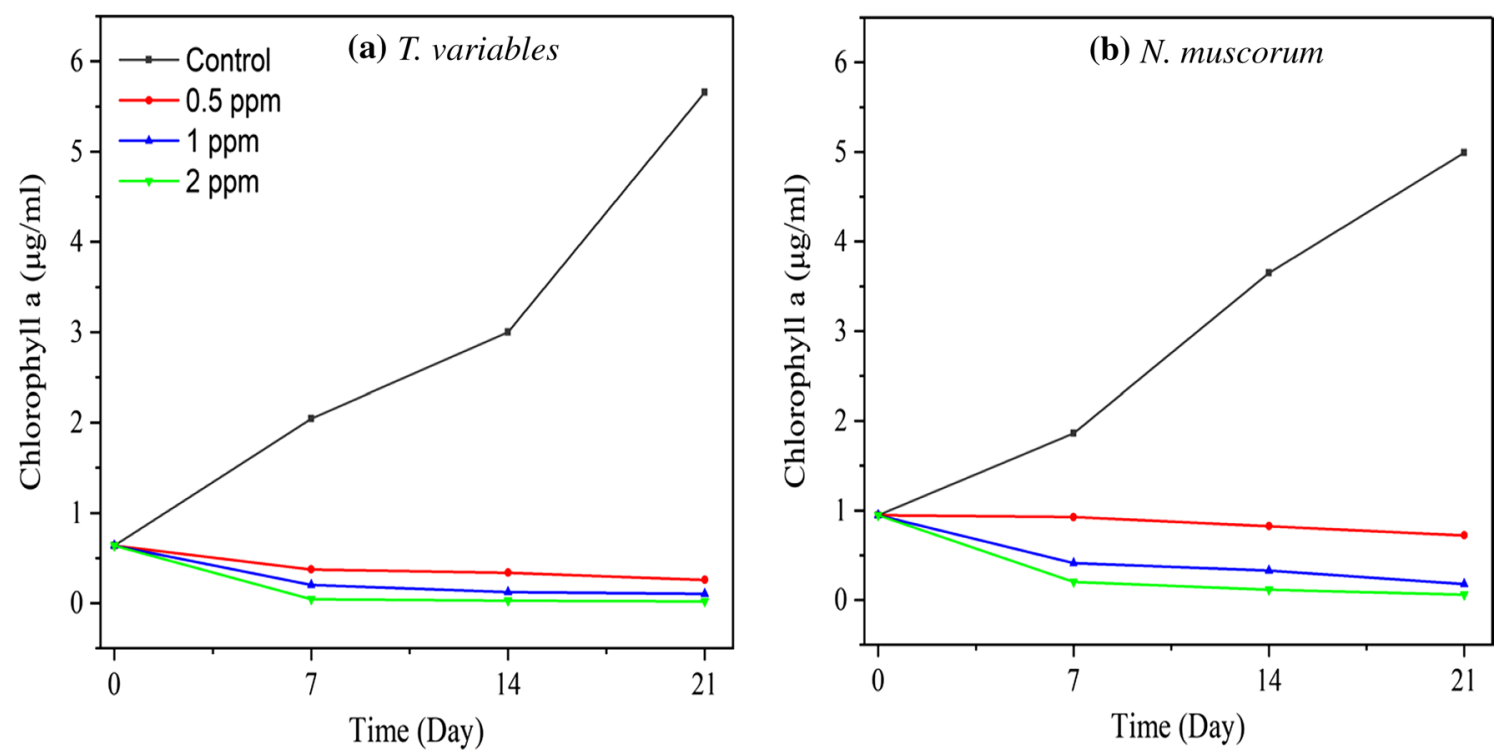

Fig. 4 Effect of $\mathrm{Cd}$ concentrations on Chlorophyll A
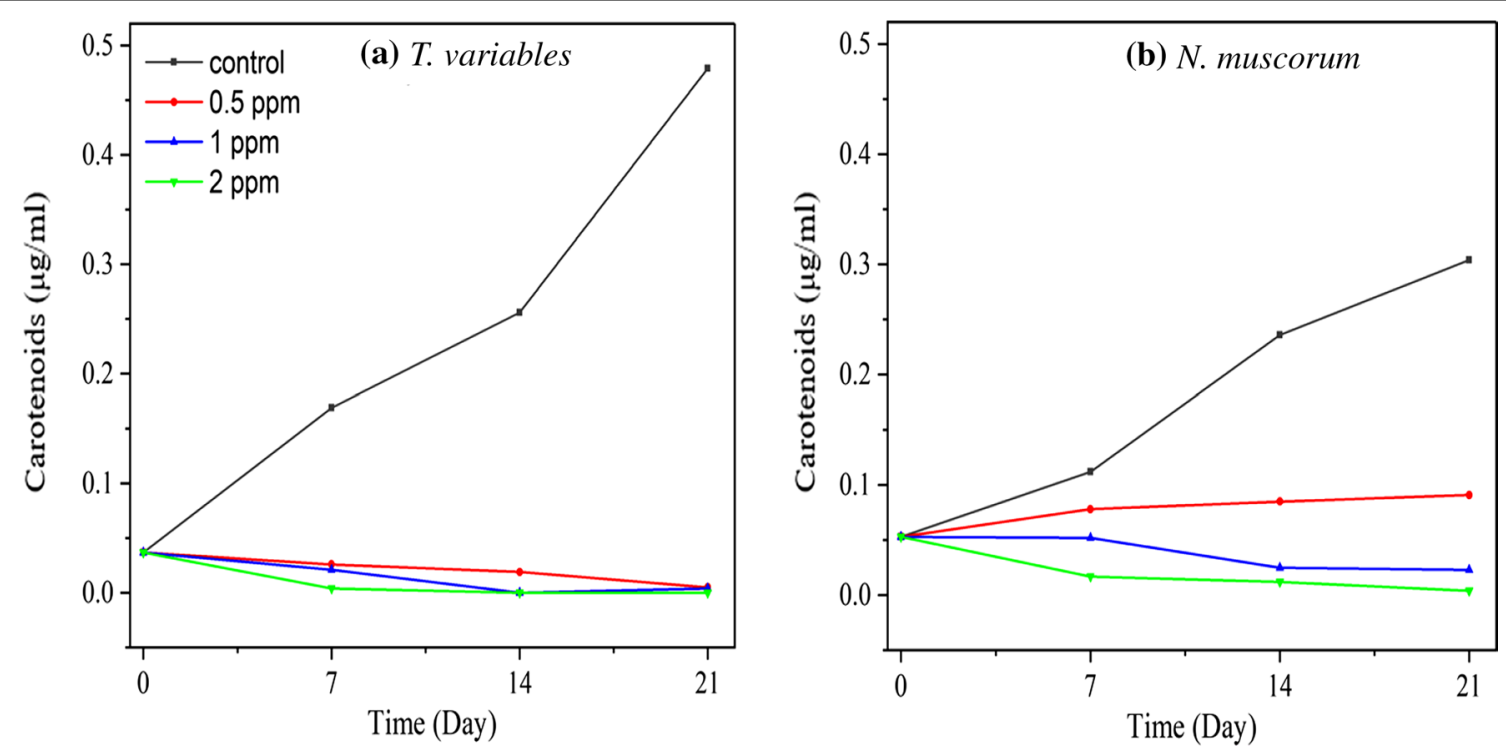

Fig. 5 Effect of $C d$ concentrations on carotenoids

corresponding values for biomass and $\mathrm{OD}_{678}$ were $78.58 \%$ and $69.5 \%$, respectively.

\section{Conclusion}

The study has presented the removal efficiency of $\mathrm{Cd}$ from contaminated water by use of two cyanobacterial strains (Trichormus variabilis and Nostoc muscorum). At the end of the 21-day study period, and for the initial metal concentration of $0.5 \mathrm{mg} \mathrm{L}^{-1}, N$. muscorum achieved a maximum removal efficiency of $\mathrm{Cd}$ of $93.4 \%$, whereas T. variabilis recorded $89.13 \%$. It is observed that $N$. muscorum is more efficient for Cd removal compared with T. variabilis. Higher concentrations of $\mathrm{Cd}$ had a more toxic effect on the growth of algae. Our study confirms the potential of cyanobacteria for phycoremediation. The removal of $\mathrm{Cd}$ from the aqueous solution was attributed to biosorption of cyanobacteria. 
Table 1 ANOVA table of the mean square values

\begin{tabular}{|c|c|c|c|c|c|c|c|c|}
\hline \multirow[t]{2}{*}{ Source of variation } & \multirow[t]{2}{*}{ DF } & \multicolumn{3}{|l|}{ Mean square } & \multirow[t]{2}{*}{ Source of variation } & \multirow[t]{2}{*}{ DF } & \multicolumn{2}{|c|}{ Mean square } \\
\hline & & Residual Cd & Biomass & OD & & & Chl. a & Carotenoids \\
\hline Replications & 2 & $0.001^{\mathrm{ns}}$ & $0.0006^{\mathrm{ns}}$ & $0.0013^{\mathrm{ns}}$ & Replications & 2 & $0.001^{\text {ns }}$ & $0.0002^{\mathrm{ns}}$ \\
\hline Algae (A) & 1 & $0.068^{* *}$ & $0.0002^{\mathrm{ns}}$ & $0.0020^{* *}$ & Algae (A) & 1 & $1.036^{* *}$ & $0.0020^{* *}$ \\
\hline Concentrations (C) & 3 & $6.002^{* *}$ & $0.0061^{\mathrm{ns}}$ & $0.0720^{* *}$ & Concentrations (C) & 3 & $36.076^{* *}$ & $0.1910^{* *}$ \\
\hline$A C$ & 3 & $0.017^{* *}$ & $0.0004^{\mathrm{ns}}$ & $0.0010^{* *}$ & $A C$ & 3 & $0.194^{* *}$ & $0.0130^{* *}$ \\
\hline Days (D) & 5 & $1.561^{* *}$ & $0.0019^{\text {ns }}$ & $0.0120^{* *}$ & Days (D) & 3 & $2.817^{* *}$ & $0.0210^{* *}$ \\
\hline$A D$ & 5 & $0.014^{* *}$ & $0.0015^{\mathrm{ns}}$ & $0.0002^{* *}$ & $\mathrm{AD}$ & 3 & $0.174^{* *}$ & $0.0020^{* *}$ \\
\hline$C D$ & 15 & $0.328^{* *}$ & $0.0003^{\mathrm{ns}}$ & $0.0110^{* *}$ & $C D$ & 9 & $0.124^{* *}$ & $0.0380^{* *}$ \\
\hline ACD & 15 & $0.001^{* *}$ & $0.0025^{\mathrm{ns}}$ & $0.0003^{* *}$ & $A C D$ & 9 & $0.126^{* *}$ & $0.0030^{* *}$ \\
\hline Error & 94 & 0.002 & 0.001 & 0.0002 & Error & 62 & 0.001 & 0.0001 \\
\hline
\end{tabular}

$\left({ }^{n s}\right)$ there was no difference between the treatments at the $5 \%$ significance level.

${ }^{(* *)}$ there was a high difference between the treatments at the $5 \%$ significance level $(P \leq 0.05)$

Table 2 Relative performance of the 3 factors (days, concentrations, and algae)

\begin{tabular}{|c|c|c|c|c|c|}
\hline Treatments & Res. Cd (ppm) & $O D_{678}$ & Treatments & Chl. a $\left(\mu \mathrm{g} \mathrm{mL}^{-1}\right)$ & $\begin{array}{l}\text { Carotenoids } \\
\left(\mu \mathrm{gL}^{-1}\right)\end{array}$ \\
\hline \multicolumn{6}{|l|}{ Algae (A) } \\
\hline$A_{1}$ & $0.364 b$ & $0.048 b$ & $A_{1}$ & $1.129 a$ & $0.079 a$ \\
\hline$A_{2}$ & $0.407 a$ & $0.056 a$ & $A_{2}$ & $0.921 b$ & $0.071 b$ \\
\hline F. Test & $* *$ & $* *$ & F. Test & $* *$ & $* *$ \\
\hline \multicolumn{6}{|c|}{ Concentrations (C) } \\
\hline $\mathrm{C}_{0}$ & $0.000 d$ & $0.118 a$ & $\mathrm{C}_{0}$ & $2.849 a$ & $0.207 a$ \\
\hline $\mathrm{C}_{0.5}$ & $0.179 c$ & $0.042 b$ & $\mathrm{C}_{0.5}$ & $0.6287 b$ & $0.049 b$ \\
\hline$C_{1}$ & $0.423 b$ & $0.027 c$ & $C_{1}$ & $0.3663 c$ & $0.027 \mathrm{c}$ \\
\hline$C_{2}$ & $0.940 \mathrm{a}$ & $0.020 c$ & $C_{2}$ & $0.2567 d$ & $0.016 \mathrm{~d}$ \\
\hline LSD & 0.0222 & 0.00702 & LSD & 0.01813 & 0.005771 \\
\hline \multicolumn{6}{|l|}{ Days (D) } \\
\hline $\mathrm{D}_{0}$ & $0.875 a$ & $0.023 f$ & $\mathrm{D}_{0}$ & $0.792 c$ & $0.045 d$ \\
\hline $\mathrm{D}_{4}$ & $0.446 b$ & $0.035 \mathrm{e}$ & $D_{7}$ & $0.758 d$ & $0.061 c$ \\
\hline $\mathrm{D}_{8}$ & $0.318 c$ & $0.047 d$ & $\mathrm{D}_{14}$ & $1.051 b$ & $0.079 b$ \\
\hline$D_{12}$ & $0.229 d$ & $0.058 c$ & $D_{21}$ & $1.500 \mathrm{a}$ & $0.114 a$ \\
\hline$D_{16}$ & $0.220 d$ & $0.066 \mathrm{~b}$ & & & \\
\hline $\mathrm{D}_{21}$ & $0.226 \mathrm{~d}$ & $0.084 a$ & & & \\
\hline LSD & 0.02563 & 0.008106 & LSD & 0.01813 & 0.005771 \\
\hline
\end{tabular}

*The same letters attached to the results indicate no significant differences at the $5 \%$ significance level $(P \leq 0.05)$

\section{Acknowledgements}

The authors would like to express their thanks to the Faculty of Agriculture, Cairo University, Agricultural Engineering Department and Plant Physiology Department for their support in this work.

\section{Authors' contributions}

MMAE-H, Shady AM and GB undertook the practical experiments. MA designed the experimental layouts and supervised all related work. MA and AM collected and analyzed the research data and wrote the original draft which was reviewed by all the authors. NA-A and YG-A edited the final manuscript. All authors read and approved the final manuscript.

\section{Funding}

No funding source.

\section{Availability of data and materials}

The researchers provided the experimental requirements of raw materials, algae, and system design through their own financial resources, while the data from previous studies and research were obtained through the Cairo University platform, which provides research on a regular basis.

\section{Declarations}

Ethics approval and consent to participate

All authors gave approval for their participation in this research.

Consent for publication

All authors consent to publication of the research paper. 


\section{Competing interests}

The authors declare no conflicts of interest.

\section{Author details}

${ }^{1}$ Agricultural Engineering Department, Faculty of Agriculture, Cairo University, Giza 12613, Egypt. ${ }^{2}$ Environmental and Natural Resources Engineering, Lulea University of Technology, 97187 Lulea, Sweden. ${ }^{3}$ Agricultural Botany Department - Plant Physiology Division, Faculty of Agriculture, Cairo University, Cairo, Egypt. ${ }^{4}$ School of Engineering and Built Environment, Griffith University, Nathan, QLD 4111, Australia.

Received: 20 August 2021 Accepted: 20 November 2021

Published online: 11 December 2021

\section{References}

1. Abdel-Aty AM, Ammar NS, Abdel Ghafar HH, Ali RK (2013) Biosorption of cadmium and lead from aqueous solution by freshwater alga Anabaena sphaerica biomass. J Adv Res 4:367-374

2. Ahad RIA, Goswami S, Syiem MB (2017) Biosorption and equilibrium isotherms study of cadmium removal by Nostoc muscorum Meg 1: morphological, physiological and biochemical alterations. Biotech 7:104

3. Ahad RIA, Syiem MB, Rai AN (2021) Cd(II) sorption by Nostoc sp. JRD1: Kinetic, thermodynamic and isotherm studies. Environ Technol Innov 21:101283

4. Alidousta L, Zahiria SH, Malekib H, Soltanic N, Valid H, Noghabi KA (2019) Nostoc entophytum cell response to cadmium exposure: a possible role of chaperon proteins GroEl and HtpG in cadmium-induced stress. Ecotoxicol Environ Saf 169:40-49

5. Antunes WM, Luna AS, Henriques CA, da Costa ACA (2003) An evaluation of copper biosorption by a brown seaweed under optimized conditions. Electron J Biotechnol 6(3):174-184

6. Arunakumara KKIU, Zhang X (2009) Effects of heavy metals (Pb2+ and $\mathrm{Cd} 2+)$ on the ultrastructure, growth and pigment contents of the unicellular cyanobacterium Synechocystis sp. PCC 6803. Chin J Oceanol Limnol 27(2):383

7. Atri N, Rai LC (2003) Differential responses of three cyanobacteria to UV-B and Cd. J Microbiol Biotechnol 13(4):544-551

8. Avigliano E, Schenone N, Volpedo A, Goessler W, Cirelli A (2015) Heavy metals and trace elements in the muscle of silverside (Odontesthes bonariensis) and water from different environments (Argentina): aquatic pollution and consumption effect approach. Sci Total Environ 506:102-108

9. Azimi A, Azari A, Rezakazemi M, Ansarpour M (2017) Removal of heavy metals from industrial wastewaters: a review. ChemBioEng 4(1):37-59

10. Cepoi L, Rudi L, Chiriac T, Codreanu S, Valuta A (2016) Biological Methods of Wastewater Treatment. Cyanobacteria for Bioremediation of Wastewaters. Springer, Cham, pp 45-60

11. Chen D, Wang XB, Wang XL, Feng K, Su JC, Dong JN (2020) The mechanism of cadmium sorption by sulphur-modified wheat straw biochar and its application cadmium-contaminated soil. Sci Total Environ 714:136550. https://doi.org/10.1016/j.scitotenv.2020.136550

12. Cheng QM, Huang Q, Khan S, Liu YJ, Liao ZN, Li G, Ok YS (2016) Adsorption of $\mathrm{Cd}$ by peanut husks and peanut husk biochar from aqueous solutions. Ecol Eng 87:240-245. https://doi.org/10.1016/j.ecoleng.2015.11.045

13. Chojnacka K, Noworyta A (2004) Evaluation of Spirulina sp. growth in photoautotrophic, heterotrophic and mixotrophic cultures. Enzyme Microb Technol 34:461-465

14. Dadar, M., Adel, M., Ferrante, M., Nasrollahzadeh Saravi, H., Copat, C. Oliveri Conti, G., 2016. Potential risk assessment of trace metals accumulation in food, water and edible tissue of rainbow trout (Oncorhynchus mykiss) farmed in Haraz River, northern Iran. Toxin Reviews, 1-6.

15. Davies BH (1976) Carotenoids. In: Goodwin TW (ed) Chemistry and Biochemistry of Plant Pigments, 2nd. Academic Press, New York, pp 38-165

16. Dixit S, Singh DP (2013) Phycoremediation of lead and cadmium by employing Nostoc muscorum as biosorbent and optimization of its biosorption potential. Int J Phytorem 15(8):801-813

17. Fipps, G., 2015. Irrigation Water Quality Standards and Salinity Management Strategies. https://www.researchgate.net/publication/26905268.

18. Fulekar MH (2010) Environmental biotechnology. CRC Press
19. Garnham GW, Godd GA, Godd GM (1992) Accumulation of Co, Zinc and Manganese by the estuarine green microalgae Chlorella salina immobilized in alginate beads. Environ Sci Technol 26:1764-1770

20. Gautam RK, Sharma SK, Mahiya S, Chattopadhyaya MC (2014) Contamination of heavy metals in aquatic media: transport, toxicity and technologies for remediation. Heavy metals in water: Presence, removal and safety. pp 1-24

21. Ghoneim MM, El-Desoky HS, El-Moselhy KM, Amer A, Abou El-Naga EH, Mohamedein LI, Al-Prol AE (2014) Removal of cadmium from aqueous solution using marine green algae, Ulva lactuca Egypt. J Aquat Res 40:235-242

22. Goswami S, Syiem MB, Pakshirajan K (2015) Cadmium removal by Anabaena doliolum Ind 1 isolated from a coal mining area in Meghalaya, India: associated structural and physiological alterations. Environmental Engineering Research

23. Guo JH, Yan CZ, Luo ZX, Fang HD, Hu SG, Cao YL (2019) Synthesis of a novel ternary HA/Fe-Mn oxides-loaded biochar composite and its application in cadmium (II) and arsenic(V) adsorption. J Environ Sci (China) 85:168-176. https://doi.org/10.1016/j.jes.2019.06.004

24. Halttunen $T$ (2008) Removal of cadmium, lead and arsenic from water by lactic acid bacteria. Functional Foods Forum; PhD. Thesis, Department of Biochemistry and Food Chemistry, University of Turku

25. Hazarika J, Pakshirajan K, Sinharoy A, Syiem MB (2015) Bioremoval of $\mathrm{Cu}(\mathrm{II}), \mathrm{Zn}(\mathrm{II}), \mathrm{Pb}(\mathrm{II})$ and $\mathrm{Cd}(\mathrm{II})$ by Nostoc muscorum isolated from a coal mining site. J Appl Phycol 27:1525-1534

26. Heimann K, Cirés S (2015) N 2-Fixing Cyanobacteria: Ecology and Biotechnological Applications. In Handbook of Marine Microalgae. pp 501-515

27. Heng LY, Jusoh K, Ling CM, Idris M (2004) Toxicity of single and combinations of lead and cadmium to the cyanobacteria Anabaena flos-aquae. Bull Environ Contam Toxicol 72(2):373-379

28. Inthorn D, Dungkokkrauad N, Incharoensakdi A (2003) Improved efficiency for the removal of cadmium from aqueous solution using cells of the cyanobacterium Phormidium angustissimum pre-treated with sodium hydroxide. Asian J Microbiol Biotechnol Environ Exp Sci 5:283-289

29. Inthorn D, Nagase H, Isaji Y, Hirata K, Miyamoto K (1996) Removal of cadmium from aqueous solution by the filamentous cyanobacterium Tolypothrix tenuis. J Ferment Bioeng 82(6):580-584

30. Inthorn D, Sidtitoon N, Silapanuntakul S, Incharoensakdi A (2002) Sorption of mercury, cadmium and lead by the use of microalgae. Science Asia 28:253-261

31. Irfan M, Hayat S, Ahmad A, Alyemeni MN (2013) Soil cadmium enrichment: allocation and plant physiological manifestations. Saudi J Biol Sci 20(1):1-10

32. Jaishankar M, Tseten T, Anbalagan N, Mathew BB, Beeregowda KN (2014) Toxicity, mechanism and health effects of some heavy metals. Interdiscip Toxicol 7(2):60-72

33. Karunanayake AG, Todd OA, Crowley M, Ricchetti L, Pittman CU, Anderson R, Mohan D, Mlsna T (2018) Lead and cadmium remediation using magnetized and non-magnetized biochar from Douglas fir. Chem Eng J 331:480-491. https://doi.org/10.1016/j.cej.2017.08.124

34. Khan S, Shamshad I, Waqas M, Nawab J, Ming L (2017) Remediating industrial wastewater containing potentially toxic elements with four freshwater algae. Ecol Eng 102:536-541

35. Khan ZH, Gao M, Qiu WW, Islam MS, Song ZG (2020) Mechanisms for cadmium adsorption by magnetic biochar composites in an aqueous solution. Chemosphere 246:125701. https://doi.org/10.1016/j.chemo sphere.2019.125701

36. Kumar KS, Dahms HU, Won EJ, Lee JS, Shin KH (2015) Microalgae - A promising tool for heavy metal remediation. Ecotoxicol Environ Saf 113:329-352

37. Kumar PS, Gunasundari E (2018) Bioremediation of Heavy Metals. Bioremediation: Applications for Environmental Protection and Management. Springer, Singapore, pp 165-195

38. Kumar PS, Pavithra KG (2018) Biosorption Strategies in the Remediation of Toxic Pollutants from Contaminated Water Bodies. Bioremediation: Applications for Environmental Protection and Management. Springer, Singapore, pp 127-163

39. Kumar V, Sinha A, Rodrigues P, Mubiana V, Blust R, De Boeck G (2015) Linking environmental heavy metal concentrations and salinity gradients with metal accumulation and their effects: a case study in 3 mussel 
species of Vito'ria estuary and Espı rito Santo bay Southeast Brazil. Sci Total Environ 523:1-15

40. Kupper H, Kupper F, Spiller M (1998) In situ detection of heavy metal substituted chlorophylls in water plants. Photosynth Res 58:123-133

41. Lam YY, Lau SSS, Wong JWC (2019) Removal of Cd (II) from aqueous solutions using plant-derived biochar: kinetics, isotherm, and characterization. Bioresour Technol Rep 8:100323. https://doi.org/10.1016/j.biteb. 2019.100323

42. Lamaia C, Kruatrachuea M, Pokethitiyooka P, Upathamb ES, Soonthornsarathoola V (2005) Toxicity and accumulation of lead and cadmium in the filamentous green alga Cladophora fracta (OF Muller ex Vahl) Kutzing: a laboratory study. Science Asia 31(2):121-127

43. Leborans GF, Novillo A (1996) Toxicity and bioaccumulation of cadmium in Olishodiscus luteus (Raphidophyceae). Water Res 30:57-62

44. Mota R, Pereira SB, Meazzini M, Fernandes R, Santos A, Evans CA, De Philippis R, Wright PC, Tamagnini P (2015) Effects of heavy metals on Cyanothece sp. CCY 0110 growth, extracellular polymeric substances (EPS) production, ultrastructure and protein profiles. J Proteomics 120:75-94

45. Mstat-c., (1989) Users guide: a microcomputer program for the design, management and analysis of agronomic research experiments. Michigan University, East Lansing, MC, USA

46. Nordberg GF, Bernard A, Diamond GL, Duffus JH, Illing P, Nordberg M, Bergdahl IA, Jin TY, Skerfving S (2018) Risk assessment of effects of cadmium on human health (IUPAC Technical Report). Pure Appl Chem 90:755-808. https://doi.org/10.1515/pac-2016-0910

47. Oboh I, Aluyor E, Audu T (2009) Biosorption of heavy metal ions from aqueous solutions using a biomaterial. Leonardo J Sci 14:58-65

48. Penido ES, Melo LCA, Guilherme LRG, Bianchi ML (2019) Cadmium binding mechanisms and adsorption capacity by novel phosphorus/magnesium-engineered biochars. Sci Total Environ 671:1134-1143. https://doi. org/10.1016/j.scitotenv.2019.03.437

49. Phang SM, Chu WL, Rabiei R (2015) Phycoremediation. the Algae World. Springer, Dordrecht, pp 357-389

50. Pourret O, Hursthouse A (2019) It's time to replace the term "heavy metals" with "potentially toxic elements" when reporting environmental research. Int J Environ Res Public Health 16:4446. https://doi.org/10.3390/ ijerph16224446

51. Prakash J, Awasthi G (2013) Accumulation of Heavy Metals in Different Water Bodies by Biological Source Algae. Adv Life Sci 2(1):10-14

52. Rehman A, Shakoori AR (2004) Tolerance and Uptake of Cadmium and Nickle by Chlorella sp., Isolated from Tannery Effluents Pakistan. J Zool 36(4):327-331

53. Rangsayatorn N, Upatham ES, Kruatrachue M, Pokethitiyook P, Lanza GR (2002) Phytoremediation potential of Spirulina (Arthrospira) platensis: biosorption and toxicity studies of cadmium. Environ Pollut 119(1):45-53

54. Ripkka R, Dereulles J, Waterbury JB, Herdman M, Stanier RY (1979) Generic assignments, strain histories and properties of pure cultures of cyanobacteria. J Gen Microbiol 111:1-61

55. Ritchie RJ (2008) Universal chlorophyll equations for estimating chlorophylls $\mathrm{a}, \mathrm{b}, \mathrm{c}$, and $\mathrm{d}$ and total chlorophylls in natural assemblages of photosynthetic organisms using acetone, methanol, or ethanol solvents. Photosynthetica 46(1):115-126

56. Rowe D, Abdel-Magid I (1995) Handbook of Wastewater Reclamation and Reuse. Inc, CRC Press, p 550

57. Singh R, Singh P, Sharma R (2014) Microorganism as a tool of bioremediation technology for cleaning environment: a review. Int Acad Ecol Environ Sci 4(1):1-6

58. Siva KRR, Madhu GM, Satyanarayana SV, Bindiya P (2012) Bioaccumulation of Cadmium in Blue Green Algae Spirulina (Arthrospira) Indica. J Biorem Biodegrad 3:141

59. Snedecor GA, Cochran WG (1976) Statistical Method. lowa State Univ. Press, Ames

60. Tchounwou PB, Yedjou CG, Patlolla AK, Sutton DJ (2012) Heavy Metals Toxicity and the Environment. Molecular, clinical and environmental toxicology. Springer, Basel, pp 133-164

61. Thornton, I., Webb, J.S., 1980. Trace elements in soils and plants. In: Blaxter, K. (Ed.), Food Chains and Human Nutrition. Springer, Dordrecht, London, pp. 273-315 https://doi.org/10.1007/978-94-011-7336-012.

62. Vieira RHSF, Volesky B (2000) Biosorption: a solution to pollution. Int Microbiol 3:17-24
63. Wang B, Gao B, Wan YS (2018) Entrapment of ball-milled biochar in Ca-alginate beads for the removal of aqueous Cd (II). J Ind Eng Chem 61:161-168. https://doi.org/10.1016/j.jiec.2017.12.013

64. Zhang HY, Yue XP, Li F, Xiao R, Zhang YP, Gu DQ (2018) Preparation of rice straw derived biochar for efficient cadmium removal by modification of oxygen-containing functional groups. Sci Total Environ 631-632:795-802. https://doi.org/10.1016/j.scitotenv.2018.03.071

65. Zinicovscaia I (2016) Water Quality: A Major Global Problem. Cyanobacteria for Bioremediation of Wastewaters. Springer, Cham, pp 5-16

\section{Publisher's Note}

Springer Nature remains neutral with regard to jurisdictional claims in published maps and institutional affiliations.

\section{Submit your manuscript to a SpringerOpen ${ }^{\circ}$ journal and benefit from:}

- Convenient online submission

- Rigorous peer review

- Open access: articles freely available online

- High visibility within the field

- Retaining the copyright to your article

Submit your next manuscript at $\boldsymbol{\nabla}$ springeropen.com 